\title{
PERENCANAAN RESORT HOTEL DI PANTAI MENGANTI KEBUMEN DENGAN PENDEKATAN ARSITEKTUR MODERN
}

\author{
Teguh Heru Winarso ${ }^{1}$,Atie Ernawati ${ }^{2}$, Karya Widyawati ${ }^{3}$ \\ ${ }^{1}$ Universitas Indraprasta PGRI, Program Studi Arsitektur \\ teguh.aruindo@email.com \\ ${ }^{2}$ Universitas Indraprasta PGRI, Program Studi Arsitektur \\ atie.ernawati@unindra.ac.id \\ ${ }^{3}$ Universitas Indraprasta PGRI, Program Studi Arsitektur \\ karya.widyawati@unindra.ac.id
}

\begin{abstract}
The infrastructure with the support of infrastructure, accommodation, promotion activities, and tourism development make the economic area around Kebumen area increase. However, this Menganti Beach tourist attraction has not been packed well with the absence of adequate accommodation facilities in the area. Then the increase of accommodation facilities will be well developed in order to further increase the number of tourists staying. The concept of modern architecture is an architectural concept that is developing at the moment by using modern materials such as industrial steel and glass to determine the interior space so as to create architecture with a structural framework that is balanced with freedom of free flowing open space. The design is expected to be able to apply the concept of climate response on the site and building through the orientation of buildings, openings and the use of secondary skin for the facade
\end{abstract}

Keywords: Kebumen, Resort Hotel, Modern

\begin{abstract}
Abstrak.Kebumen dengan dukungan infrastruktur,akomodasi,kegiatan promosi, dan pengembangan kawasan wisata menjadikan kawasan ekonomi di sekitar kawasan Kebumen meningkat. Akan tetapi obyek wisata Pantai Menganti ini belum di kemas dengan baik dengan tidak adanya sarana akomodasi yang memadai di kawasan tersebut. Maka peningkatan sarana akomodasi akan di kembangkan dengan baik guna lebih memperbanyak jumlah wisatawan yang menginap. Konsep arsitektur modern merupakan konsep arsitektural yang sedang berkembang pada saat ini dengan menggunakan material modern seperti baja industri dan kaca untuk menentukan ruang interior sehingga menciptakan arsitektur dengan kerangka struktur yang di seimbangkan dengan kebebasan ruang terbuka yang mengalir bebas. Desain yang di harapakan yaitu mampu menerapakan konsep respon terhadap iklim pada tapak dan bangunan melalui orientasi bangunan,bukaan dan penggunan secondary skin untuk fasad
\end{abstract}

Kata Kunci :Kebumen, Resort Hotel, Modern

\section{PENDAHULUAN}

Prospek perkembangan dunia pariwisata di Kebumen di masa mendatang diyakini banyak pihak cukup menjanjikan dan berpeluang untuk dikembangkan. Sektor pariwisata Kabupaten Kebumen di masa mendatang akan terus meningkat karena pangsa pasarnya yang masih besar dan banyak kegiatan promosi pariwisata berskala regional maupun nasional diadakan di Kebumen. Salah satu potensi obyek wisata yang banyak diminati banyak wisatawan baik domestik maupun mancanegara adalah wisata alam berupa pantai dan laut,hal tersebut sejalan dengan meningkatnya berbagai fasilitas akomodasi dan fasilitas penunjangnya seperti terjadi di pantaipantai pulau Jawa, Bali dan pulau-pulau lain di Indonesia. Pantai Menganti memiliki potensi wisata alam yang sangat indah. Kondisi saat ini menurut data yang dimiliki Dinas Pariwisata dan Budaya Kebumen, di Kebumen tercatat hanya ada beberapa hotel dan penginapan yang tersebar di kawasan kota dan kabupaten Kebumen yang tidak banyak. Namun semua itu berada pada wilayah yang lumayan jauh dari kawasan objek Pantai Menganti, serta posisi geografis yang cukup strategis, serta memiliki kekhasan dari kondisi alamnya obyek Pantai Menganti cukup potensial untuk dijual kepada wisatawan.Namun obyek wisata tersebut belum dikemas dalam paket wisata yang profesional seperti tidak adanya sarana akomodasi di kawasan tersebut.

Melihat kondisi ini perlu adanya upaya peningkatan sarana akomodasi guna lebih memperbanyak jumlah wisatawan yang menginap, khususnya bagi pangsa pasar menengah kebawah. Sedangkan, potensi pantai 
Menganti pemandangan alam, kondisi klimatologi, topografi di kawasan pantai Menganti yang belum dimanfaatkan, dapat diupayakan pengembangannya sebagai fasilitas kesehatan dan relaksasi yang selanjutnya dapat dikembangkan menjadi wisata kesehatan.

Masih banyak peluang obyek dan daya tarik wisata yang dapat digali dari Pantai Menganti, mengingat fasilitas yang tersedia saat ini masih minim terutama pada sarana akomodasi , sehingga dengan kehadiran Resort Hotel ini maka akan menjadi peluang investasi dalam rangka pengembangan obyek wisata Pantai Menganti. Tema Resort ini menggunakan tema terasering karena letak dari resort ini yang berada di perbukitan membentuk terasering dengan metode perancangan dengan menggunakan arsitektur modern sehingga akan menambah daya tarik pengunjung untuk datang ke resort ini.

\section{METODOLOGI}

Proses Pengumpulan Data

\section{a. Data Primer}

Data yang diperoleh dari pengamatan secara langsung dengan orang-orang yang berkecimpung di dalamnya. Dalam proses ini penulis melakukan beberapa metode, diantaranya sebagai breikut :

1) Observasi lapangan

Observasi lapangan dilakukan pada lokasi tapak yaitu di Desa Karangduwur,kecamatan

Ayah,kabupaten Kebumen,Jawa Tegah. Keuntungan metode ini dapat merasakan langsung kondisi dan suasana dilapangan, sehingga dapat membantu dala proses perancangan. Berdasarkan hasil pengamatan diperoleh beberapa data diantaranya :

1. Ukuran tapak.

2. Kondisi kontur tapak.

3. Kondisi vegetasi dilokasi tapak.

4. Kondisi sistem drainase, listrik dan telfon di lokasi tapak.

5. Batas-batas yang mengelilingi tapak.

6. Kondisi umum sosial masyarakat disekitar tapak.

7. Kondisi umum sitem transportasi dan lebar jalan.

8. Suasana tapak yang meliputi iklim, angin, topografi tanah

9. serta data-data yang lain yang ada di lokasi tapak.

2) Wawancara

Wawancara dilakukan untuk mendapatkan data-data yang lebih detail yang dibutuhkan mengenai kebutuhan ruang, aktivitas pemakai, serta opini tentang segala sesuatu yang berhubungan dengan proses perencanaan resort hotel.

3) Dokumentasi

Dokumentasi merupakan metode yang melingkupi proses observasi dan wawancara yang sudah dilakukan. Dalam hal ini dokumentasi yang dihasilkan berupa foto. Pada perancangan resort hotel di Kebumen foto tapak yang dihasilkan meliputi foto kondisi eksisting di tapak dan sekitarnya serta foto suasana kawasan.

4) Tinjauan Proyek Sejenis

Dilakukan untuk mendapatkan data terkait dengan objek dan tema perancangan. Studi ini dilakukan untuk bagaimana penerapan perancangan objek pada bangunan yang telah ada. Metode ini bisa dilakukan dengan pengambilan unsur-unsur perancangan yang bemilai positif dalam objek tinjauan dan memasukanya dalam desain rancangan baru yang direncanakan.

\section{b. Data sekunder}

Aspek perancangan untuk menunjang keberhasilan fungsinya perancangan bangunan komersial perhotelan perlu mempertimbangkan berbagai aspek yang meliputi :

1) Pencitraan (brand image ),dimana bangunan komersial harus mempunyai citra atau karakter yang kuat sebagai daya tarik untuk menarik konsumen.

2) Nilai ekonomis,bangunan dimana bangunan ini mudah perawatanya sehingga tercapai efisiensi dalam pengunaan dimana erat kaitanya dengan keuangan.

3) Lokasi strategis,sehingga mudah di lihat,di cari dan di jangkau.

4) Prinsip keamanan bangunan,sebagai persyaratan utama dalam bangunan komersial karena mewadahi keselamatan 
publik seperti tangga darurat,peralatan keselamatan dari kebakaran maupun antisipasi untuk bencana alam lain. Prinsip kemanan bangunan ini di bedakan menjadi safety (keselamatan ) dan security (keamanan ).

5) Prinsip kenyamanan bangunan,bangunan komersial akan lebih memberikan keuntungan apabila mampu membuat si penghuni maupun konsumen betah di dalamnya.

6) Kebutuhan jangka panjang,aspek ini penting untuk mengantisipasi dinamika perubahan baik dari waktu maupun tuntutan kebutuhan.

7) Kondisi,potensi dan karakter kawasan,aspek ini akan menunjang lancarnya ekonomi bangunan komersil ini,karenanya harus ada kesesuaian antara kondisi,potensi dan karakter kawasan dengan fungsi bangunan komersial yang akan di adakan.

8) Kondisi sosial budaya masyarakat,aspek ini untuk mendukung lancarnya kegiatan perekonomian dimana bangunan komersial dengan kegiatanya ini harus bisa di terima oleh masyarakat sekitarnya secara sosial,budaya maupun psikologis.

9) Perkembangan teknologi,dimana di harapkan bangunan komersil ini mampu menerima atau bahkan dapat menerapkan perkembangan teknologi yang ada sehingga bisa memberi manfaat lebih bagi sekitarnya.।

\section{HASIL DAN PEMBAHASAN}

\section{a. Tinjauan tapak}

Lokasi pembangunan resort hotel berada di kecamatan Ayah Kab.Kebumen,Jawa Tengah.Batasan lokasi secara administratif sebelah utara Desa Kalipoh,sebelah selatan Samudera Indonesia,Sebelah barat samudra Indonesia dan sebelah timur samudera indonesia.
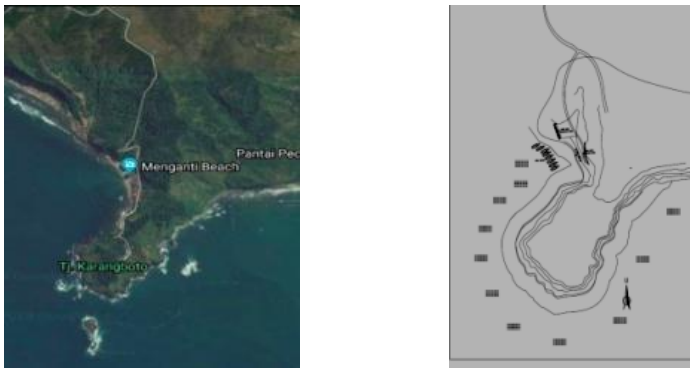

Gambar 1. Lokasi dan Layout Tapak

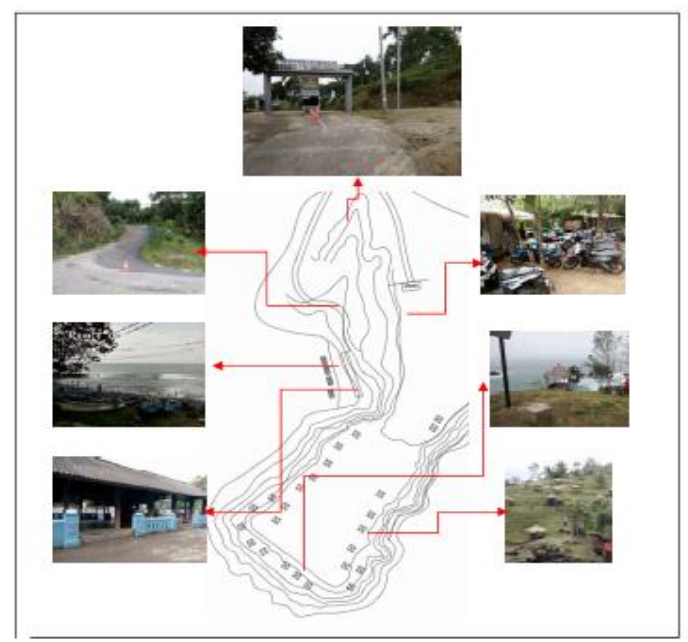

Gambar 2. Tapak Kondisi sekitar Tapak

a. Kondisi sekitar tapak

1. Lingkungan dan orientasi bangunan sekitar

Tapak berada di kawasan yang agak berbukit bukit

2. Kondisi tanah di sekitar tapak berkontur

3. Objek wisata di sekitar tapak

Pada sekitar tapak terdapat obyek wisata yang dapat di singgahi oleh wisatawan

Tabel 1. Objek Wisata sekitar Site

\begin{tabular}{|l|l|l|l|}
\hline No & Obyek Wisata & Jarak dg Lokasi & Gambar \\
\hline 1 & $\begin{array}{l}\text { Pantai } \\
\text { Logending }\end{array}$ & $5,8 \mathrm{~km}$ & \\
\hline 2 & $\begin{array}{l}\text { Pantai Karang } \\
\text { Bolong }\end{array}$ & $6,4 \mathrm{~km}$ & \\
\hline 3 & Pantai & $3,4 \mathrm{~km}$ & \\
\hline
\end{tabular}


b. Kondisi sarana dan prasarana

1. Air bersih

Air bersih pada tapak di peroleh dari sumber yang berada bukit di sebelah timur kawasan.

2. Sampah

Kawasan ini mempunyai pembuangan sampah berupa lubang tanah yang di gunakan sebagai tempat pembuangan sampah.

3. Listrik

Jaringan listrik di kawasan menggunakan listrik yang di suplai oleh Perusahaan Listrik Negara.

\section{b. Analisa view}

Di sebelah utara merupakan tanah kosong Jl Pantai Menganti dan di situ terdapat banyak pepohonan. Di sebelah timur tanah kosong dan disitu terdapat banyak pepohonan . Di sebelah barat dan selatan memiliki karakter visual yang unik dan potensi yang sangat besar dilihat dari kondisi fisik dan studi pandang tentang site, yang berupa suatu pemandangan dan orientasi ke arah perairan laut (pantai).

1)

Analisa view ke dalam tapak

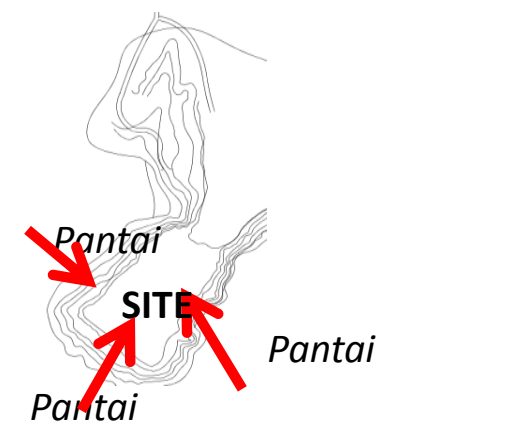

$\begin{array}{ll}\text { Posisi bangunan } & \text { Tidak adanya } \\ \text { berada di bukit } & \text { perantara } \\ \text { memugkinkan } & \text { pandangan } \\ \text { pandangan dari } & \text { dari luar } \\ \text { luar ke dalam } & \text { tapak } \\ \text { langsung di } & \text { sehingga } \\ \text { tangkap } & \text { bangunan } \\ & \text { dapat terlihat } \\ & \text { dari luar } \\ & \text { tapak }\end{array}$

Gambar 3 Pandangan ke dalam Tapak

a) Posisi bangunan berada di bukit memungkinkan pandangan dari luar ke dalam langsung ditangkap.

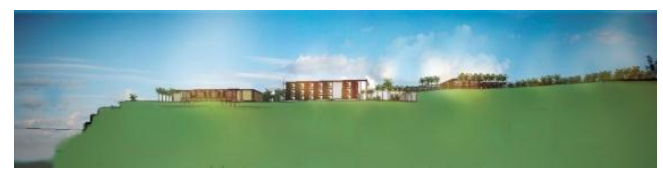

Gambar 4. Pandangan dari luar ke dalam Tapak

b) Membuat gapura pada entrance sehingga menjadikan tapak mudah di kenali oleh pengunjung.

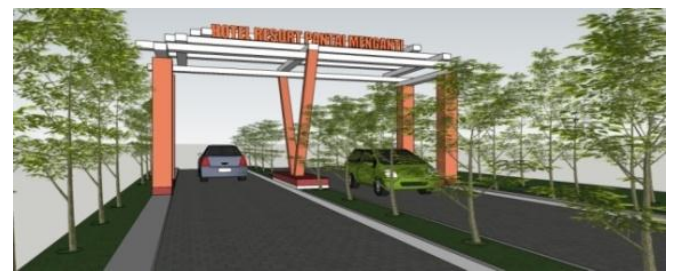

Gambar 5. Gapura untuk Pengenalan Site

c) Memberikan vegetasi sebagai penutup pada area private (kamar Hotel ).

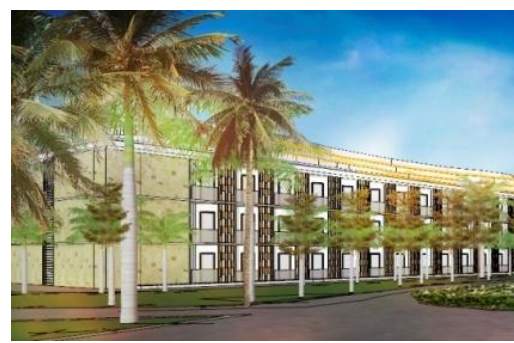

Gambar 6. Vegetasi penutup area private

2) Analisa view ke luar tapak

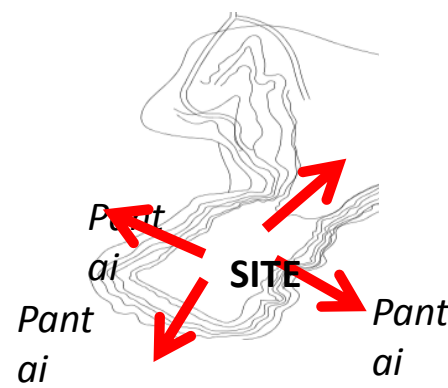

Orientasi
pemandan
gan ke arah
laut
laut

\section{Orientasi pemandang an ke arah laut}


Tanggapan orientasi view atau pemandangan yang bagus yaitu pandangan langsung ke arah ke laut.

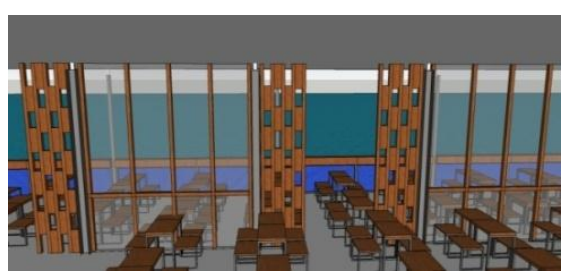

Gambar 8. View keluar bangunan restoran

Mengarahkan view bangunan pada bangunan utama menghadap kelaut

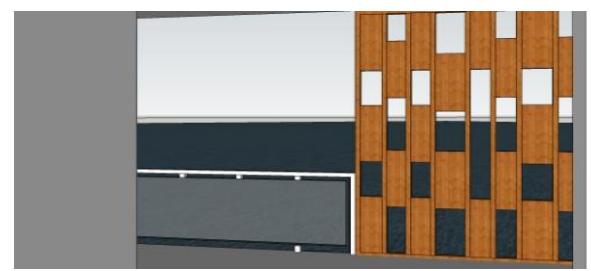

Gambar 9. View keluar bangunan hotel

\section{c. Analisa matahari}

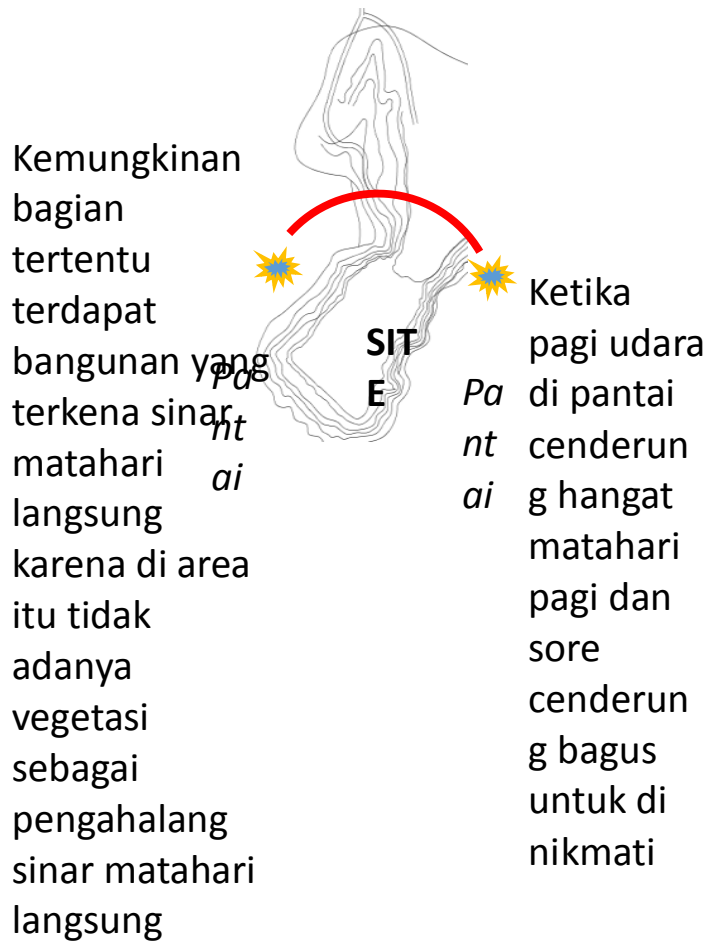

Gambar 10. Analisa cahaya matahari
Analisa cahaya matahari:

a. Umumnya, sudut elevasi sinar matahari berubah yang berpengaruh pada bayangan sinar dan cahaya yang masuk dalam area tapak.

b. Ketika pagi udara di Pantai cenderung hangat, matahari pagi dan matahari sore cenderung bagus untuk di nikmati

c. Kemungkinan pada bagian tertentu terdapat bangunan yang terkena sinar matahari langsung, karena di area-area ini tidak adanya vegetasi sebagai penghalang sinar matahari langsung, terutama pada sore hari.

\section{Solusi alternatif}

1) Pemberian vegetasi pada depan bangunan yang terkena sinar matahari secara langsung
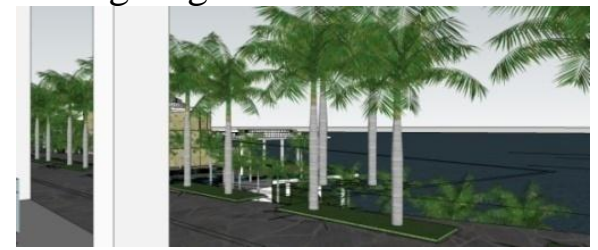

Gambar 11. Pemberian Vegetasi

2)

Diberikan kisi-kisi pada areaarea tertentu yang terkena sinar matahari secara langsung.
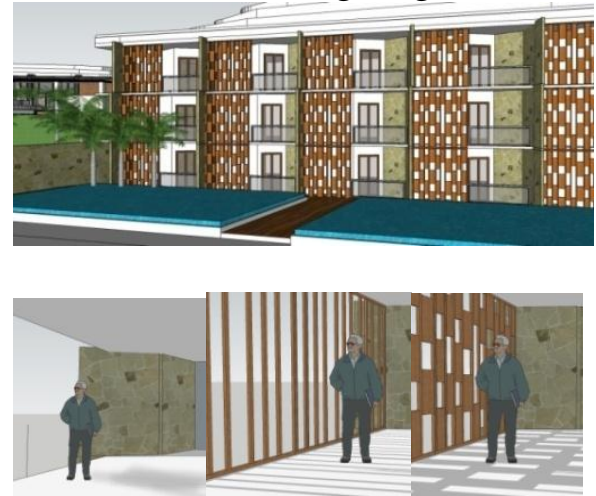

Gambar 12. Pemberian kisi-kisi

3)

Menjadikan kayu sebagai penutup lantai dan atap agar suasana ruangan menjadi hangat.

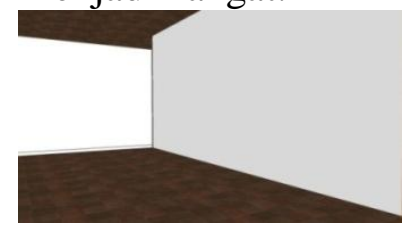

Gambar 13. Finishing kayu pada lantai dan plafond 


\section{d. Analisa angin}

Analisa pada tapak paling besar berasal dari arah selatan,sedangkan pada sisi timur,barat dan utara angin tidak terlalu kencang karena sudah ada vegetasi di dalam site.

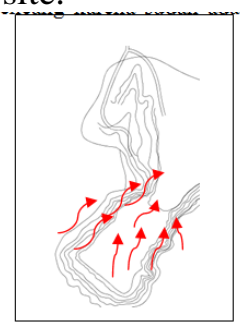

Gambar 14. Analisa Arah Angin

1) Penataan vegetasi yang rapat sebagai pemghalang,pengarah dan penyerap angin
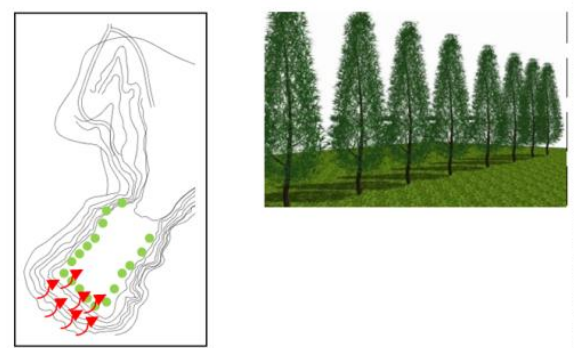

Gambar 15. Arah angin dan peletakan vegetasi

2) Penggunaan kisi-kisi bangunan untuk memecah angin

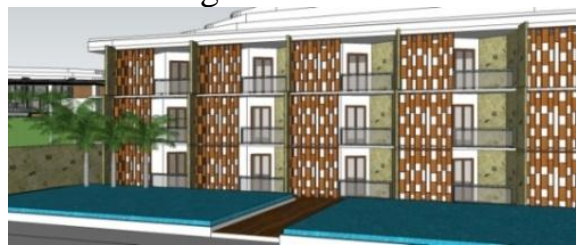

Gambar 16. Arah angin dan peletakan vegetasi

3) Tata masa bangunan linier yang mengarahkan angin. Dengan pola linier angin akan mudah di arahkan dan melewati sisi bangunan.

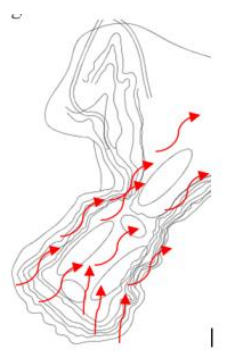

Gambar 17. Bentuk linier mengarahkan angin pada bangunan
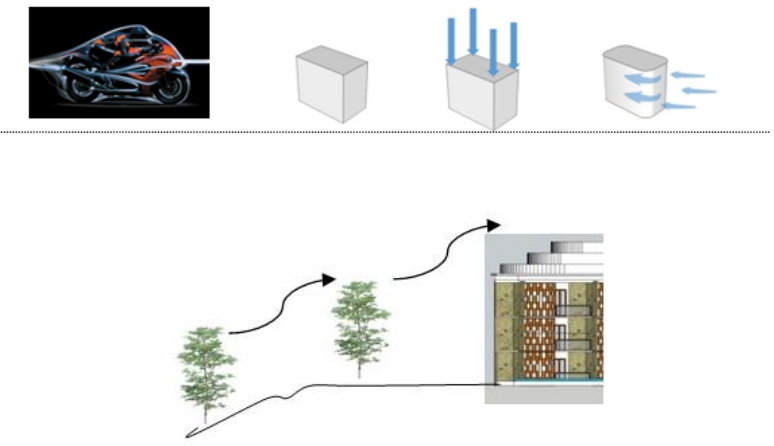

Gambar 18. .Konsep aerodinamika

\section{e. Desain}

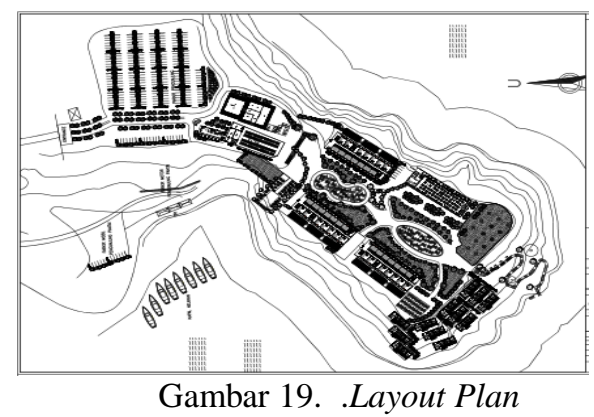

1)

$\mathrm{Pe}$

rspektif

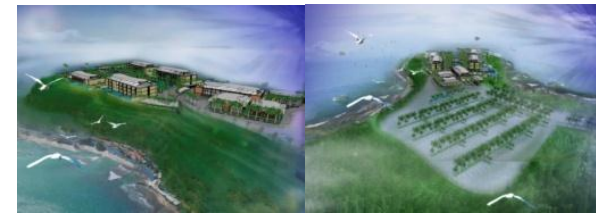

Gambar 20 .Aerial view

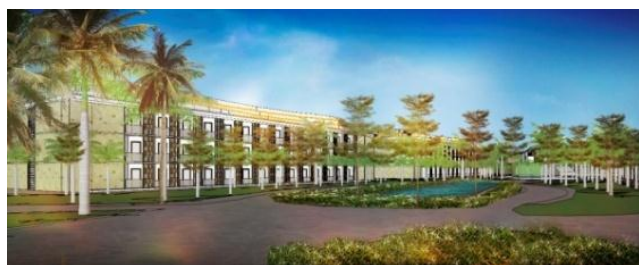

Gambar 21. Bangunan utama

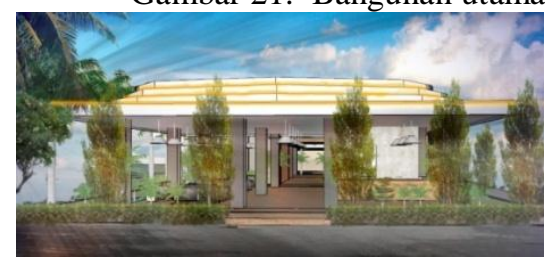

Gambar 22. Looby 

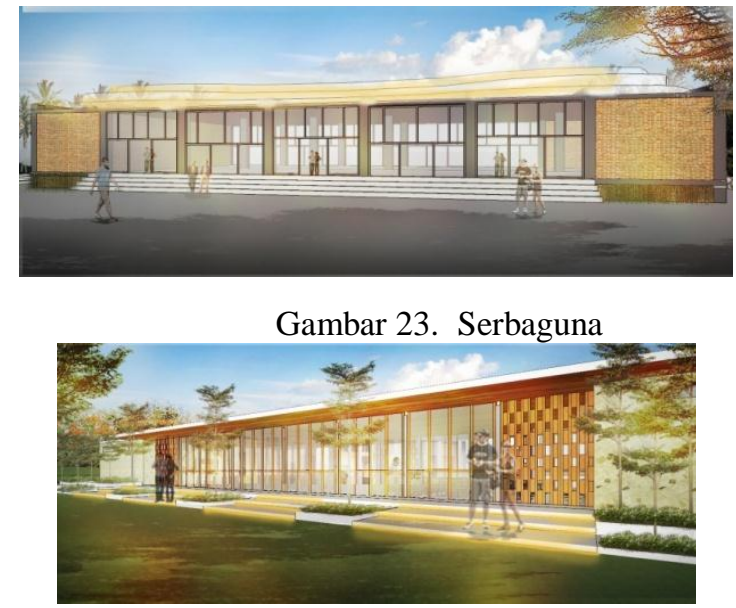

Gambar 24. Restoran

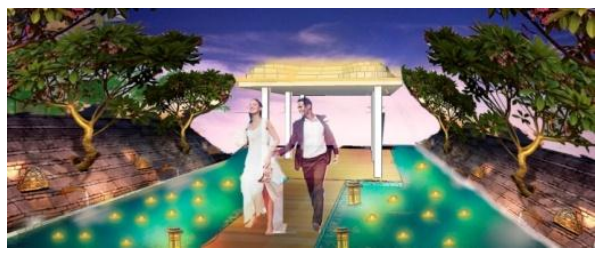

Gambar 25. Wedding

1)

nah Bangunan Utama

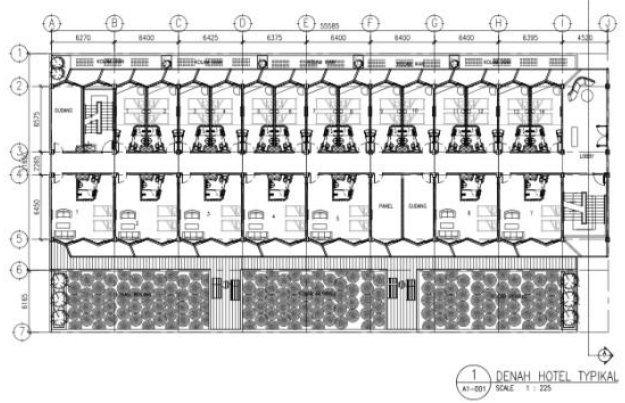

Gambar 26. denah bangunan utama

2) nah Ball room

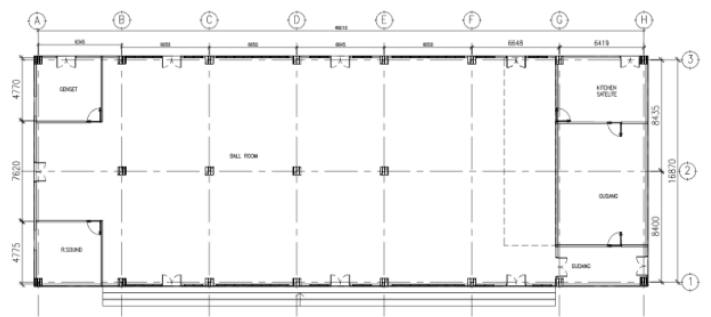

DENAH BaLROROM

Gambar 27. denah ball room

3)

ngunan pengelola

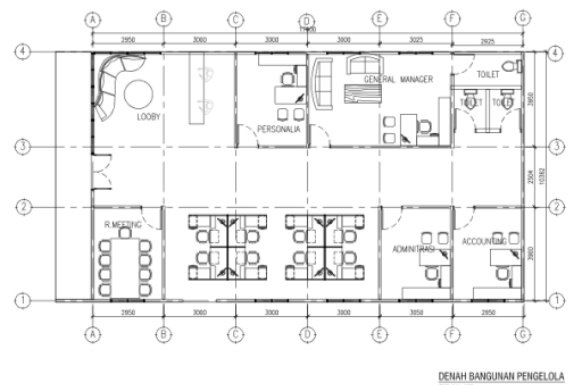

Gambar 28. denah pengelola

4)

De

nah restoran

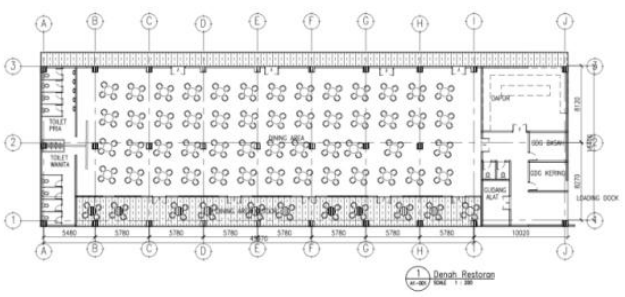

Gambar 29. denah restoran

5) Denah lobby

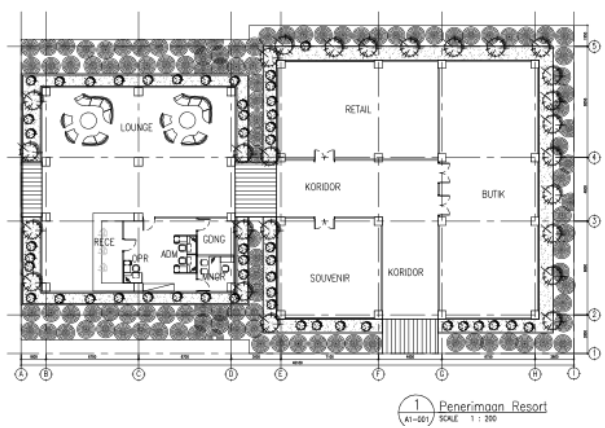

Gambar 30. denah Lobby

6) Denah Villa

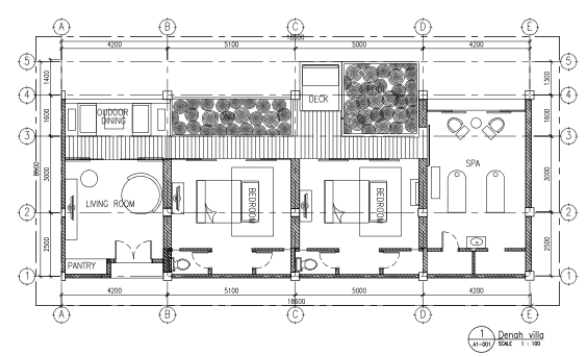

Gambar 31. denah Villa

\section{PENUTUP}

\section{Simpulan}

Selain letak lokasi yang mempunyai view dengan pemandangan yang indah yaitu mengarah ke laut perencanaan Resort Hotel Di Pantai Menganti bertujuan untuk mendorong kemajuan kota Kebumen khususnya dibidang pariwisata. 


\section{Saran}

Tugas akhir ini masih jauh dari sempurna sehingga bila ada kesalahan dalam penulisan dan perencanaan saya sebagai penulis mohon maaf sebesar-besarnya. Selanjutnya tugas akhir ini diharapkan dapat berguna bagi khalayak umum atau bagi para pembaca semua. Saya mengucapkan terima kasih kepada para pembaca yang dapat memberikan saran yang berguna bagi Proyek selanjutnya. Akhir kata saya mengucapkan selamat membaca

\section{DAFTAR PUSTAKA}

Frick, Heinz. ( 2003). Membangun dan Menghuni Rumah di Lerengan. Yogyakarta:Kanisius

Sumalyo,Yulianto.(2005).Arsitektur Modern Ahir abad $x 1 x$ dan abad xx, Jakarta:Gajah Mada Universitas press

Triatmojdjo,Bambang,Yulianto.(2011).Perencan aanBangunan Pantai,Jakarta:Betta Ofset Tjahyadi ,Sunarto.Edisi $33 \quad$.Data

Arsitek,Jakarta:Erlangga

Sumaryoto,dkk.(2015).Pedoman penulisan Skripsi/Tugas Akhir.Jakarta:Universitas Indraprasta PGRI

Laksito,Boedhi.(2013).Metode Perencanaan \& Perancangan Arsitektur, Jakarta :Griya Kreasi

Akmal,Imelda.(2011).50 Indonesian Houses+ Villas,Jakarta: Imaji+

Arik,S.(2011).Perancangan resort hotel novotel sentul city, 1 (2)hlm.50-52

Andana,D.(2011).Hotel resort rawa pening.(skripsi).Universitas Mercu Buana,Jakarta.

Website

http://koran-sindo.com/page/news/2016-0105/6/75 Diakses pada November 2017

http://www.rancang.net/. Diakses pada November 